\title{
BOTANICAL STUDIES ON THE MICROPROPAGATION OF TWO DRIED CV(S) FROM DATE PALM (phoenix dactylifera, L.) USING TISSUE CULTURE TECHNIQUE. 2-CARBOHYDRATES FRACTIONS AND ACCLIMATIZATION. Helaly, M.N.*; A. E. A. Hegazy ${ }^{\star *}$ and Hanan A. M. El-Hosieny * \\ * Agric Bot . Dep. Faculty of Agric Mansoura Univ., Egypt \\ ** Genetic engineering Inst and Bio- technology Menofia Univ.
}

\begin{abstract}
Bartamuda cv has higher level of all carbohydrates fractions studied and least values of total proteins, amino acids and proline concentrations compared with Sakkoty cv overall the developmental stages. The possibility that Sakkoty cv can form specific protein types for adaptation was suggested.

The concentrations of reducing sugars, non reducing sugars and total sugars were increased whereas total protein and amino acids were decreased with subculturing. The lowest significant values of carbohydrate fractions and the highest values of total protein, amino acids and proline were noticed at the embryogenic stage. Polysaccharides and insoluble sugars were decreased gradually in Bartamuda cv. whereas in Sakkoty cv, up to the embryonic callus and thereafter increased .

The interaction treatments showed that, the highest significant value of carbohydrates fractions were recorded with Bartamuda cv at initial explant and callus stages in addition to Sakkoty cv at only the callus stage. The lowest significant values were found with Sakkoty cv at the embryogenic stage. At plantlet stage, a slight increases in all carbohydrates formations concentrations were noticed, but still less than the corresponding calculated values recorded at stages of the initial shoot tip explants and callus initiations. Total protein and amino acids were decreased at callus stage gradually up to the embryogenic callus and thereafter increased at plantlet stage to reached vales more than the corresponding initial explant. These results are true in the two cv (s) studied.
\end{abstract}

\section{INTRODUCTION}

Date palm (phoenix dacylifera L.), a monocotyledonous and dioecious species belonging to the Palmaceae; Arecaceae family (200 genera and over 2500 species; Tomlinson, 1961). It is one of the most important and oldest fruit crop in Egypt. It is used also as an ornamental plants as well as a source of fiber, fuel and furniture uses (FAO, 2004) ${ }^{1}$. Dates produced about 680,000 tons fruits from about 9,463,911 millions fruitful femal plants which decreased continusly from the last century by about $12-15 \%$ from the total number of dates(FAO, 2004). The missing may be due to the national developmental industries projects, in addition to desease infection, reduction in the cultivated area, practices and the growth habit.

\footnotetext{
${ }^{1}$ FAO (2004). Food and Agricultural Organization Year Book
} 
Helaly, M.N. et al.

To protect date palm from extinction in Egypt, there is an important to propagated and cultured it in the new reclaimed soil, especially is Toshakey and Shark El-Aoinat. These regions demand the dry $\operatorname{cv}(\mathrm{s})$ of dates similar to that grown in Aswan governorate.

Dates propagated, in most species, either by seeds or vegetatively through offshoots. Seed propagation is not used commercially due to heterozygosity. Moreover, many problems associated with vegetative propagation were detected. The number of offshoots are rare during date palm's life; and mostly during the juvenile stage. Plant tissue culture was introduced to the public as an asexual method for large scale propagation and commercial production; rapidly and reliably.

Somatic embryogenesis from shoot tip explant derived callus has been viewed as the most appealing process for date palm regeneration (AlKhayri, 2001) This method has proved feasibility and agronomic acceptability justifying scale-up of micropropagation multiplication for commercial purposes. The typical somatic embryogenesis protocol for date palm involves a series of consecutive stages beginning from callus induction, embryogenic callus multiplication, somatic embryos formation, somatic embryos germination (shoot formation from embryos) and finally rooting.

It becomes necessary to find out the best protocol for dried $\mathrm{cv}(\mathrm{s})$ date palm micropropagation. Thereafter, the present investigation aimed to optimize regeneration protocol for the specific genotypes; Bartamuda and Sakkoty cv(s) using explant tissues from the mother female suckers using indirect embryogenesis technique. The biochemical constituentes of the explant tissues throughout the micropopagation steps as well as plantlet acclimatization present were studied.

\section{MATERIALS AND METHODS}

The present investigation was carried out at the plant tissue culture Dept .,Genetic of Engineering and Biotechnology Research Institute(G E B R I) EL-Sadat city ,Menofia Unvi. Egypt and the Laboratories of Agric.Bot.Dept ., Faculty of Agric. Mansoura Univ. Egypt, during the period of 2003-2007.

Femal date palm (phoenix dactylifera, L),Bartamuda and Sakkoty $\mathrm{cv}(\mathrm{s})$, which commonly known as an important dried $\mathrm{cv}(\mathrm{s})$ grown at Aswan governorate ,Egypt were used for micropropagation indirect embryogenesis. Biochemical analyses of some biological moleclules as well as plantlet acclimatization percent were examined .

Sterilized explants (Shoot tip segments) were initially cultured on MS basal nutrient media supplemented with $170 \mathrm{mg} / \mathrm{l} \quad \mathrm{NaH}_{2} \mathrm{PO}_{4} \mathrm{~L}_{2} \mathrm{H}_{2} \mathrm{O} ; 200 \mathrm{mg}$ glutamine ; $40 \mathrm{mg} / \mathrm{l}$ adenine sulphate $; 0.4 \mathrm{mg} / \mathrm{l}$ thiamine- $\mathrm{HCl}, 3 \mathrm{~g}$ actiiveted charcoal / litre in absence or presence of $5 \mathrm{mg} / \mathrm{l}$ from either of NAA, 2,4-D, or NOA in addition to $32 \mathrm{iP}$. Stages of callus initiationembryos friable callus, somatic embryo formation and shoot multiplication were carried out as previously mentioned (El-Hosieny, Hanan, 2008).

The specific nutrient media of each treatment was dispensed into jars $(150 \mathrm{ml})$ at the rate of $35-40 \mathrm{ml} / \mathrm{jar}$. Each treatment was replicated 8 times $(8$ 
jars), each of them was used for sterilized specific explant used. All culture jars were maintained in the complet darkness in the controlled growth room at $25 \pm 1^{\circ} \mathrm{C}$ for 24 weeks.

Developed shoots of date palm Bartamuda and Sakkoty cv(s), which were obtained and formed from shooting stage and having 2-3 foliage leaves; $5-7 \mathrm{~cm}$ in length, were transferred and cultured in cultured glass tubes (25X150 mm; Borosil) capped with Bellco plastic caps and dispersed with $15 \mathrm{ml}$ of MS basal nutrient medium supplemented with $3 \mathrm{~g} / \mathrm{l} A C$ and auxins treatments (mg/l) as follows: MS alone (control) , MS + $1 \mathrm{NAA}, \mathrm{MS}+$ 2 NAA, MS +1 IBA, MS + 2 IBA, MS + 1 2,4-D and MS + 22,4-D

Each treatment was replicated four times and each replicate contained one developed shoot. The specific explants tubes were incubated at the same conditions which described before in the shooting stage for 8 weeks with two subculture at four weeks on fresh specific media.

For acclimatization, twenty one produced plantlets were chosen at the end of rooting stage to find out the percentage of survived plantlets throughout the acclimatization period. They were transferred from the cultured glass tubes, and treated with Rizolex $5 \%$ fungicide $(2 \mathrm{~g} / \mathrm{l})$ for 20 minutes and planted in plastic pots; tyrpido $(5.5 \times 6.5 \mathrm{~cm})$ containing mixtures of peatmoss, perlite and washed sand at equal volume $(1: 1: 1)(\mathrm{v} / \mathrm{v} / \mathrm{v})$ as recommended (El-Hosieny, Hanan, 2002)). Natural day light at about 70008000 Lux light intensity for $16 \mathrm{hrs}$ photoperiod and temperature of $27 / 15^{\circ} \mathrm{C}$ day/night were recorded.

Hardening was took place for 48 weeks from transplanting. Throughout the hardening period, commercial Crystalone nutrient solution $(20: 20: 20)$ at the rate of $1.0 \mathrm{~g} / \mathrm{l}$ was added to pots every two weeks. Percentage of survived plantlets, number of leaves and plant height were recorded periodically every 12 weeks.

The best treatments produced highest growth throughout the developmental stages of the explants $(\mathrm{MS}+5 \mathrm{NAA}+32 \mathrm{iP}+3 \mathrm{Kin}$ and $\mathrm{MS}+2$ IBA) were used for chemical constituents analysis.

Total soluble carbohydrates (sugars) and free amino acids were extracted from one $\mathrm{g}$ fresh material of the examined explant from each cv by ground in mortar with $20 \mathrm{ml}$ ethanol $70 \%$ and kept overnight at room temperature (Kayani et al., 1990) before being filtred.

For sugar estimation, protein was precipitated by using trichloroacetic acid; TCA (A.O.A.C 2000) and filtred. Further filtration was carried out and the cleared solution was made up to $25 \mathrm{ml}$ with isopropanol. Reducing sugars (R.S) were estimated in the isopropanol extract using phenol-sulphuric acid method (Dubois et al, 1966). Ten $\mathrm{ml}$ of the cleared sugars extract previously mentioned, were used for estimation non-reducing sugars (NRS), (Naguib, 1964). Total carbohydrates, as glucose, were determined in a well known volume from the acidic-isopropanol extranet after protein precipitation and neutralization according to Amberger (1954) . Total Amino N; Free Amino Acid (Plummer 1978), and proline concentrations (Bates, et al, 1973) were also determined. 1984).

All data were subjected to statistical analysis (Gomez and Gomez 


\section{RESULTS AND DISCUSSION}

\section{Carbohydrates Fractions:-}

Data presented in Table I show that, Bartamuda cv has higher level of all carbohydrates fractions studied compared with Sakkoty cv overall the developmental stages. It exceeded in sugars, about 2-3 fold, than the Sakkoty due to the gene action.

Table 1: Effects of Date palm genotype, culturing developmental stage and their interaction on carbohydrate fraction concentrations (mg/g F.Wt).

\begin{tabular}{|c|c|c|c|c|c|c|}
\hline \multirow[b]{2}{*}{$\begin{array}{l}\text { Genotype } \\
\text { (cv) }\end{array}$} & \multirow[b]{2}{*}{$\begin{array}{l}\text { Developmental } \\
\text { stage }\end{array}$} & \multicolumn{5}{|c|}{ Carbohydrate fraction concentration $\mathrm{mg} / \mathrm{g} \mathrm{F.Wt}$. } \\
\hline & & $\begin{array}{l}\text { Reducing } \\
\text { sugars }\end{array}$ & \begin{tabular}{|c|} 
Non- \\
Reducing \\
sugars
\end{tabular} & $\begin{array}{c}\text { Total } \\
\text { sugars }\end{array}$ & $\begin{array}{c}\text { Poly } \\
\text { saccharides }\end{array}$ & $\begin{array}{c}\text { Total } \\
\text { Carbohydrate }\end{array}$ \\
\hline \multirow[t]{6}{*}{ Bartamuda } & Explant & 10.00 & 20.32 & 31.32 & 126.33 & 157.66 \\
\hline & Callus & 10.06 & 20.06 & 30.12 & 120.00 & 150.12 \\
\hline & Embryogenic C & 4.48 & 7.96 & 12.44 & 89.60 & 102.00 \\
\hline & Embryo & 5.46 & 10.74 & 16.20 & 84.66 & 90.86 \\
\hline & Plantlet & 6.12 & 12.54 & 18.66 & 72.33 & 90.99 \\
\hline & Mean & 7.22 & 14.53 & 21.75 & 98.58 & 118.33 \\
\hline \multirow[t]{6}{*}{ Sakkoty } & Explant & 3.24 & 6.39 & 9.63 & 86.66 & 96.29 \\
\hline & Callus & 10.39 & 20.78 & 31.17 & 90.33 & 121.50 \\
\hline & Embryogenic C & 5.18 & 10.21 & 15.39 & 60.33 & 75.72 \\
\hline & Embryo & 2.66 & 5.14 & 7.80 & 86.00 & 93.80 \\
\hline & Plantlet & 2.94 & 5,98 & 8.82 & 85.66 & 94.48 \\
\hline & Mean & 4.88 & 9.70 & 14.56 & 81.80 & 96.36 \\
\hline \multirow[t]{4}{*}{ Mean } & Explant & 6.62 & 13.36 & 20.50 & 106.50 & 126.98 \\
\hline & Callus & 10.23 & 20.42 & 30.65 & 105.17 & 135.81 \\
\hline & Embryogenic C & 4.83 & 9.09 & 13.92 & 74.97 & 88.86 \\
\hline & Embryo & 4.06 & 7.94 & 12.00 & 85.33 & 92.33 \\
\hline \multicolumn{2}{|c|}{$\begin{array}{l}\text { N- LSD at } 5 \% \text { for } \\
\text { Genotype; } \mathrm{A}:\end{array}$} & & 0.10 & 0.11 & 0.11 & 1.20 \\
\hline \multicolumn{2}{|c|}{ Developmental stage; B } & & 0.19 & 0.17 & 0.17 & 1.72 \\
\hline \multicolumn{2}{|c|}{$\begin{array}{l}\text { GenotypeXDevelopmental } \\
\text { stage }(\mathrm{AxB})\end{array}$} & & 0.77 & 0.96 & 0.96 & 3.13 \\
\hline
\end{tabular}

Regarding the effects of the developmental stage overall, the genotype, date also show that, reducing sugars; RS , non reducing sugars; NRS and total sugars; T.S were increased at the callus stage as compared to the other developmental stages and thereafter decreased. The lowest significant values were noticed at embryogenic stage. Polysaccharides, PS and total sugars; TS were decreased gradually in Bartamuda cv

In Sakkoty cv, there is a sudden increase reached to the maximum in polysaccharides; PS and total sugars; TS at callus stage thereafter, decreased at the embryonic callus and tended to increase again up to the plantlet stage.

These results, strongly, suggested a positive correlation between the developmental stage and sugar accumulation potential with special referring to the superiority of Bartamuda plant which greatly exceeded the Sakkoty cv in their sugar concentration. 
Moreover, it was found that, non reducing sugars; NRS were affected by the developmental stages than reducing sugars; RS especially with Baramuda cv which recrded more vigour growth than Sakkoty cv, and did not suffer relatively from hyperhydricity. This could be explanted as due to capabitily of Bartamuda cv to established powerful sink of stress. Helaly et al, (1985 a and b) attributed the decrease in polysaccharides under stresses to the increase in hydrolytic enzymes activities. Consequently, the sugars was increased causing a rise in osmotic potential.

As for the effect of interactions between genotype and the developmental stags, it was found that the highest significant value of carbohydrates fractions were recorded with Bartamuda cv at ST explant and callus stages in addition to Sakkoty cv at only the callus stage.

The lowest significant values were found with Sakkoty cv at the embryogenic stage. At plantlet stage, a slight increases in all carbohydrates formations concentrations were noticed, but still less than the corresponding calculated values recorded at stages of shoot tip; ST explants and callus initiations.

The increase in sugars at plantlet stages may be alternated to the increase in osmotic pressure of the cell sap and resistance of water absorption by hardening plants (El-Housieny, Hanan, 2002) Thus, explants most expend more energy produced by intense respiration to absorb water and nutrients required for continous growth. This could be attained by nutrient accumulation or by increasing the intermediate substances of organic products synthesized such as different sugars and organic acids (Helaly, 1977). The later subcultures, may then combined with other inorganic ions particularly amino acids, $\mathrm{N}$ and other, thus causing an increase in concentrations of the resultant substances at the expense of the total carbohydrate concentration which is consequently reduced.

Ismail (2005) pointed out that the promotion of carbohydrate in plants grown under stress culture was limited in two way: firstly, an adjustment in the internal osmotic pressur of the cell sap to go along with the external media by mean of salt accumulation or increasing the intermediate substances of organic product. Secondly, a production of high energy by means of respiration in order to overcome the relatively low availability condition of water and nutrient elements in stress media ; since carbohydrates are the principle substances used in respiration, a depression in the carbohydrate concentrations in plants grown under growth intduction factors could be expected. Nasir et al (2000) postulated that osmoregulation in stressed tissues was higher in $\mathrm{K}^{+}$, free proline and sugars.

The high values of sugar accumulation at callus stage confirmed a positive correlation between the magnitude of stress intensity and sugar accumulation potential with special referring to the superiority of cv Sakkoty which recorded the highest value compared with Batamuda cv.

The accumulation of much more sugars in the Sakkoty cr as a mechanism of stress tolerance during this stage increased their ability to extract more water from the media. Since plant tissues to maintain a continuous water uptake must decreases the internal water potential, sugars 
and $\mathrm{K}^{+}$contribute to lowering osmotic potential under stress (Salem et al, 2002).

Because carbohydrates are the principal substance used in respiration, a depression in the carbohydrate concentration of stressed plants may occur, which using for cell division and forming new cells callus and embryos (El-Housieny, Hanan, 2002)

The high values of reducing sugars; RS, non reducing sugars; NRS , total sugars; T.S noticed at callus stage especially with Sakkoty cv may be due to a sparing effect, resulting from disturbances in metabolism, such as slowing down of glycolysis, Krebs, cycle and amination reactions and consequently, sugar accumulation. Similar conclusion were reported previously by (Ismail, 2005) who reported that the accumulation of carbohydrate in plants grown under stress conditions was more rapid than their utilizration for the formation of new cells and tissues.

Total Proteins, Amino Acids and Proline

The mean values of total proteins; T.P, total amino acids;A. A and total proline concentrations in Sakkoty cv were considerably higher than those corresponding in Bartamuda cv. (Table 2 )The possibility that Sakkoty $\mathrm{cv}$ can form specific protein types for adaptation was suggested.

Table 2 : Effects of Date palm genotype, culturing developmental stage and their interaction on total protein, total amino acids and total proline concentrations (mg/g F.Wt).

\begin{tabular}{|c|c|c|c|c|}
\hline genotypes & $\begin{array}{l}\text { Developmental } \\
\text { stage }\end{array}$ & $\begin{array}{l}\text { Total } \\
\text { protein }\end{array}$ & Total A.A & $\begin{array}{c}\text { Total } \\
\text { proline }\end{array}$ \\
\hline \multirow{6}{*}{ Bartamuda } & Explant & 13.2 & 4.59 & 2.28 \\
\hline & Callus & 11.1 & 3.96 & 1.94 \\
\hline & Embryogenic & 14.1 & 6.28 & 1.74 \\
\hline & Embryo & 16.7 & 7.83 & 5.28 \\
\hline & Plantlet & 18.6 & 9.02 & 7.08 \\
\hline & Mean & 14.74 & 6.34 & 3.66 \\
\hline \multirow{6}{*}{ Sakkoty } & Explant & 14.6 & 7.70 & 3.66 \\
\hline & Callus & 4.5 & 4.17 & 3.33 \\
\hline & Embryogenic & 7.3 & 8.38 & 3.10 \\
\hline & Embryo & 8.6 & 9.15 & 6.66 \\
\hline & Plantlet & 9.9 & 10.07 & 6.99 \\
\hline & Mean & 6.98 & 7.89 & 4.75 \\
\hline \multirow{5}{*}{ Mean } & Explant & 3.9 & 6.15 & 2.97 \\
\hline & Callus & 2.8 & 4.07 & 2.64 \\
\hline & Embryogenic & 5.7 & 7.33 & 2.42 \\
\hline & Embryo & 7.65 & 8.49 & 5.97 \\
\hline & Plantlet & 9.25 & 9.55 & 7.04 \\
\hline \multicolumn{5}{|c|}{ N-LSD at $5 \%$ for: } \\
\hline \multicolumn{2}{|l|}{ Genotype ; A } & 0.20 & 0.07 & 0.20 \\
\hline \multicolumn{2}{|c|}{ Developmental stage ; B } & 0.23 & 0.10 & 0.05 \\
\hline \multicolumn{2}{|c|}{ GenotypeXDevelopmental stag:(AxB) } & 0.71 & 0.56 & 0.20 \\
\hline
\end{tabular}


Consiedering the changes of total protein and amino acids concentrations, it appeared, generally, that protein substances was affected by the $\mathrm{cv}(\mathrm{s})$ used, developmental stages and their interactions.

The accumulation of much more quantities of total protein, as well as proline and other amino acids in Sakkoty cv compared with Bartamuda cv offered strong evidence on the broad and confirmed correlation between resistance and the genotype. Sallam (1999) found that, stress increased solute accumulation; proline, sugars, free amino acid and protease; proteinase which induced plants exposed to many biotic or abiotic stress to tolerate these condition. Meinzer et al, (1990) added that, compatible solutes; sugars, proline, amino acid, organic acids and protein, have the role of adjusting the osmotic potential of the cytoplasm to that of the vacuole, thus, maintaining an osmotic equilibrium between the two cell compartment. Jeffrey, (1987) showed a similar response between RNA and DNA as well as proteins. This is very linkely to occur, because the binding of ribosomes to $\mathrm{m}$ RNA is very sensitive to ionic balances and their concentrations.

The two cv (s), in the present investigations, gave similar trend regarding the developmental stages. The concentrations of total protein; T.P and total AA were decreased with subculturing at callus stage, and thereafter, increased reached to its maximum at plantlet stage and exceeded than that of the corresponding initial explant by about two to three fold. The rate of increase was found to be highest in Sakkoty cv compared with Bartamuda. However total proline concentrations was decreased at callud and embryogenic callus stages and thereafter increased. Similar results were reported by other investigators with different plant species. In this context, Zain El-Din, Amal (2005) found that, phenol content at maturity was higher than at differentiation. The correlation between development of $\mathrm{O}_{2}$ impermeability and deposition of high level of polymerized phenols indicates that these two processes may be linked (Hatung, 2004). Zain El-Din, Amal (2005) found that, the phenolic compound were declined slowly with the developmental stage up to maturity.

As for the effects of the interaction treatments betweens the developmental stages, and the genotype used, the same table and Fig show that total protein and amino acids were decreased at callus stage whereas proline was decreased gradually up to the embryogenic callus and thereafter increased in plantlets to reached vales more than the corresponding initial explant. These results are true in the two cv (s) studied, and it seem to be correlated with the ability of plants to survive the sever conditions. Therefore, the pattern noticed for the developmental stages of a given proteins and amino acids depended in most cases, upon the cv used. The concentration of proline amino acid, one of the Krebs cycle dependent group, was found to be high in Sakkoty cv compared with Bartamuda cv. These results are true thoughtout the various developmental stages. Moreover, the decreasing or increasing rates (data not presented) was found to be more notices in $\mathrm{cV}$ Sakkoty than those in Bartamuda cv. The hindering activity of stress on the concentration of the Krebs cycle dependent group of protein amino acides may be due to the disturbances occurring in protein metabolism and its assimilation as well as the hydrolysis of protein under stress, which alter the 
amounts and kinds of chemical components found in plant tissues such as $\mathrm{N}$ metabolism. (Helaly et al, 1985 a, b). Pierik (1989) found that addition of glutamine, argenine and asparagines amino acids minimize browning. Moreover Booij et al (1993 a) showed divergences in sugars and amino acids compositions of date palm strains. They could suppose that variations were introduced by the micropropagation technique. The in vitro technique used for the multiplication of cultivars has perhaps not allowed the maintenance of their physical and chemical properties, at least for the chemical composition of sugars and free amino acids. Binzell and Reuveni (1994) found that under stress condition, the accumulation of non toxic substances such as sucrose, proline, organic acid, pigments, nucleic acids and protein is considerd to be protective adaptation and that the survival of plant tissues under stress depends upon the regulation of metabolic processes and the quantitative ratio between the protective and the toxic metabolic intermediate.

The role of protein and amino acids; $\mathrm{A}$. $\mathrm{A}$ in the adaptive response to stress has also been reported (Hatung, 2004). Ismail (2005) pointed out that, in plant tissues, substances are formed which protected the plasma colloids from the coagulation effect of electrolytes such substances may be hydrophilic proteins. The increase in protein and amino acids; A.A concentrations, noticed at the embryogenic and plantlets stages might be attributed to an accumulated synthesis of adaptive protein under media condition. The hormonal modification in the media composition on protein metabolism was also recorded (Hatung, 2004).

It may be concluded that, stress of the media increased the total amino acids; TAA especially proline to induce the tissue to withstand the negative effects of stress especially under the two late stages. The decrease in total protein concentration at callus stage may be attributed to the effects of growth media on the inhibition of RNA synthesis within the plant tissues which was correlated to $\mathrm{N}$ fraction (Ismail, 2005).

The results, in the present investigation, might suggest that, under tissue culture technique, protein may converted into free amino acids, as a result of water stress especially in the presence of $\mathrm{Fe}, \mathrm{Mn}$ and/or $\mathrm{Zn}$ to insure the cell soluble content. Cheng (2003) reported that under the physiological stress conditions the high molecular weight compounds, such as protein, are converted into low molecular weight compounds, such as free amino acids, to increase the soluble content of the cell.

The increase in total protein, amino acids and proline concentrations in the initial explants and regenerated plantlets may be due to the media composition and the presence of nutrients especially that of $\mathrm{Zn}, \mathrm{Fe}$ and $\mathrm{Mn}$ in its components which affected on the adaptive system in date palm tissue culture controlling protein metabolism (Hatung, 2004).

The resistance of tissue in the culture media may depends upon the changes in the physiological and biochemical characterization of tissue under the influence of culture condition. Such changes include greater protein content. Ismail (2005) strongly concluded that, the function of proline in resistance is that of osmoregalation function. It is suggested also that, S-S bonds may play an important role in the mechanism of biological control (Hatung, 2004) who added that. the increase of $\mathrm{SH}$ group during hardening is 
due to protein SH and not to glutathione SH. Passaraki (2002) found that the endogenous concentrations of free proline in the plant tissue can be used as an indicator for resistance. These measurements of proline concentration. can be used to determine plant tissue resistance. Moreover, proline and other compatible solutes are believed to cause the minimal inhibition of metabolism. Proline is organic osmolytes solute with an amphiphilic molecules protects the hydrophobic proteins parts of proteins which suffer first when water potential is lowered. By forming association with the hydrophilic proteins of macro molecules proline converts than into hydrophilic parts. Ghallab et al (2004) reported the over produced proline may be explained on the basis that osmogenes (osmiosmotic tolerance genes) govern the production of a class of molecules such as betain and proline that protect the cell and its constituents against osmotic stress "dehydrationosm" . Hardening Stage (Acclimatization)

Data in Table 3 and Fig 1show that, date palm plantlets produced from MS media supplemented with either of IBA, NAA or 2,4-D auxins showed high percentage of survived plantlets which ranged from 45 to 55 percentage after 48 weeks from hardening compared with about $5 \%$ at the same date with MS free auxins (control) overall genotype and acclimatization period. Rooting without hormone resulted in the development of fine ramified roots that were unable to survive hardening. The most effective treatments on increasing surviving was found with IBA followed by NAA and 2,4-D in a descending order and the high level, $2 \mathrm{mg} / \mathrm{l}$, was preferable. Plantlet height showed similar trend to that of surviving and IBA was the best followed by NAA or 2,4-D respectively and the increase was a concentration dependent. Similarly, number of leaves was increased significantly in the plantlets pretreated with either of the auxins used compared with the control. However, the differences between the auxins-treated plants were insignificant in most causes. These results are true in the $\mathrm{cv}(\mathrm{s})$ examined.

As for the effect of the acclimatization period data in the same table, reveal that percentage of survived plantlet was decreased whereas plantlet height and number of leaves were increased with an increase in the acclimatization period. Percentage of surviving was decreased from about $70 \%$ at 12 weeks to about $50 \%$ at 48 weeks from hardening in both $\mathrm{cv}(\mathrm{s})$. The decreasing rate was found to dependent on the hardening period, it is high at the beginning and decreased at the later stage. These results are true overall treatments used and genotype examined. On the other hand, plantlet height as well as number of leaves were increased showly with an increase in hardening period overall treatments used or genotypes examined.

Regarding the effects of interaction treatments between auxins used and genotype, data in the same table and fig show that, IBA at $2 \mathrm{mg} / \mathrm{l}$ gave the highest percentage of survived plant in both Bartamuda and Sakkoty $\mathrm{cv}(\mathrm{s})$ followed by NAA at $2 \mathrm{mg} / \mathrm{l}$ and IBA at $1 \mathrm{mg} / \mathrm{l}$ and the treatment of 2,4-D at $2 \mathrm{mg} / \mathrm{l}$ recorded lowest percentage $(57.5 \%)$ in Bartamuda and 55\% compared with the control (13.75 and $18.75 \%$ in Bartamua and Sakkoty cv(s) respectively). Data also indicated that the high level of IBA followed by NAA at $2 \mathrm{mg} / \mathrm{l}$ were preferable than the low level at $1 \mathrm{mg} / \mathrm{l}$. However, 2,4-D at 1 $\mathrm{mg} / \mathrm{l}$ was more effective than that it at $2 \mathrm{mg} / \mathrm{l}$ in both $\mathrm{cv}$ (s). Plant heigh and 
Helaly, M.N. et al.

3

2050 
number of leaves showed an increase in both $\mathrm{cv}$ (s) due to auxins pretreatment. The increase was found to be dependent on the growth substances used and genotype. IBA followed by NAA gave best results and the increase was a concentration dependent, it increased with an increase in their levels. Moreover, it was found that 2,4-D increased number of leaves and plant height but the low level $(1 \mathrm{mg} / \mathrm{l})$ was preferable in both $\mathrm{cv}(\mathrm{s})$.

As for the effect of genotype, it was found that Bartamuda plantlet showed highest percentage of surviving with dwarfism and are being evaluated in field for agronomic traits compared with Sakkoty throughout the acclimatization period. However, plantlet height was found to be at high value in Sakkoty compared with Bartamuda throughout the acclimatization period. Number of leaves showed insignificant different between the two $\operatorname{cv}(\mathrm{s})$. These resulrs are true at any auxin treatments and thought the acclimatization period of date palm propagated by indirect embryogenesis. Data also demonstrate efficient cloning of female suckers of the two genotypes date palm through somatic embryogenesis. The morphogenic potential of cultures could be maintained for 48 weeks with a high vigorous growth.

Although the variation in vitro protocols of regeneration through somatic embryogenesis in date palm have been reported, there were limitations like nonsynchronous plant production or poor field survival. It depends on the auxin level and the genotype specific.

Date palm, similar to other plant species, grown in vitro condition and aseptic media require an acclimatization process. The number of survived plantlets and its vigorously depend on growth media and environmental condition as well as the acclimatization period. However, there is no significant differences between the two genotype under the investigation.

Most species grown in vitro condition and aseptic media require an acclimatization process. The number of survived plantlets and its vigorously depend on growth media and environmental condition.

Al-Salih et al, (1985) found that, in vitro plantlets of date palm Braim cv failed to grow and died when transferred in pots containing soil media. They attributed this to the lack of root cell differentiation in the plantlets caused by a deficiency in growth substances insufficient sugars or hormonal and/or sugar imbalances. Moreover, in vitro plantlets were generally smaller in size, thinner and weeker than seedlings. Because of the lack of endodermis and conductive tissues (xylem and phloem) in the plantlets root system, in vitro plantlets could

not replace water losses caused by transpiration in the low humidity condition of open pot culture.

Tisserat (1981a) found that, plantlets of date palm can be successfully transferred to $1: 1$ peat:vermiculite mixture when they reach about $12 \mathrm{~cm}$ in length and have distinct tap root and 2-3 leaves.

Tisserat (1981b and 1982) showed that, survival was best $(100 \%$ after 8 weeks) in $10-12 \mathrm{~cm}$ plantlets of date palm transferred to a peat:vermiculite mixture and covered with transparent plastic.

Tisserat (1984a\&b) described in detail a procedure for establishment of in vitro developed date palm plantlets in soil media. The initial size of the plantlets was a critical factor in their survival. A minimum height averaging 
Helaly, M.N. et al.

between 10 and $12 \mathrm{~cm}$ appeared to be necessary for maximum survival on transplantation.

Mater (1986a) examined the effects of vermiculit and sphagnum peat media alone and in combination mixtures and found that the vermiculit medium alone was superior for surviving date palm plantlets. The survival percentages in vermiculite media reached to $88 \%$ whereas in peat alone and $1: 1$ mixture of peat and vermiculit being $76 \%$ and $29 \%$, respectively.

The noticed decrease in the survival rate at the first weeks of acclimatization primarily due to rapid desiccation of plantlet and sometimes fungal build up. However the survival rate could be increased effectively if plantlet were passed through a pre-acclimatization phase in controlled growth room with an air exchange area as reported by Bhargava et al, (2003) on date palm who found that doubling the air exchange area $\left(7.85 \mathrm{~cm}^{2}\right)$ decreased palm who found that doubling the air exchange area $\left(7.85 \mathrm{~cm}^{2}\right)$ decreased the survival rate significantly whereas further increase (39.80 $\mathrm{cm}^{2}$ ) in air exchange area of pre-acclimatization chambers caused severe decline in the survival rate.

In the recent protocol on date palm micropropagation Sharon and Shanker (1998) have regenerated plantlets through direct organogenesis pathway, however, field survival of hardened plantlets was poor. Several investigators conducted studied to established the optimum conditions for successful transfer using in vitro regenerated date palm plants. Plant height 10-15 cm, with 2-3 leaves had a direct effect on ex vitro success percentage (Al-Jibouri et al, 1988), well rooted plants $8-12 \mathrm{~cm}$ in height (Quraishi et al, 1997), hardened off under high light and low nutrient levels before transfer to sterilized soil, thereafter at high humidity and under low temperature for 8 weeks followed by a few weeks under net house benches before open transferred (Bhansalia and Kaul, 1991), hardened on a 1:1 mixtrue of vermiculite and peatmos in the greenhouse prior to transfer to the outdoors (Sharon and Shanker, 1998)

El-Hosieny, Hanan, (2002) in a previous study on date palm Zaghloul $\mathrm{cr}$ found that, the percentage of survived plantlets was decreased with an increase in acclimatization period up to 36 weeks. However, less decrease, in general, was recorded at 48 weeks overall different mixtures media. Comparing the effects of different mixtures media, it was found that peatmoss : sand : perlite $(1: 1: 1 \mathrm{v} / \mathrm{v})$ gave the best results in this respect. Number of leaves/plantlet and plantlet height were increased with an increase in hardening period. The best treatment which gave high values of leaf number and plant height was peamoss : sand : perlite $(1: 1: 1 \mathrm{v} / \mathrm{v})$. However, using perlite alone gave lowest values in this respect. 


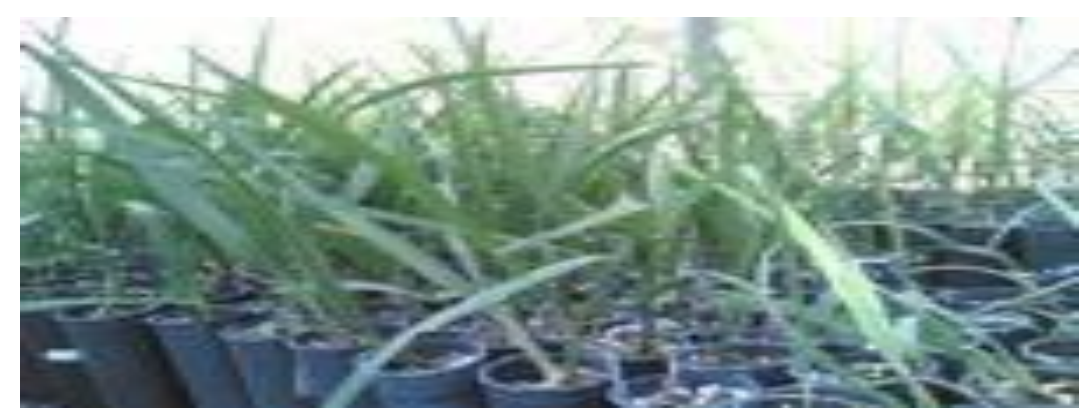

B

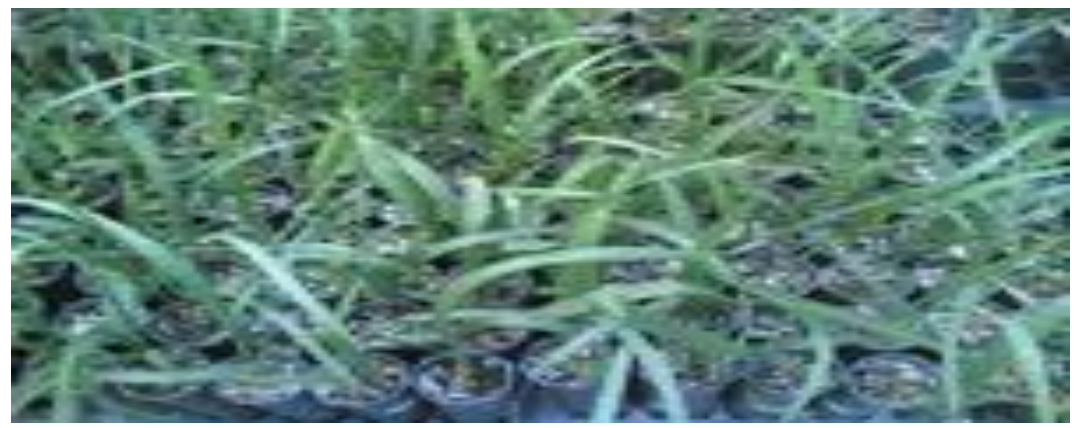

S

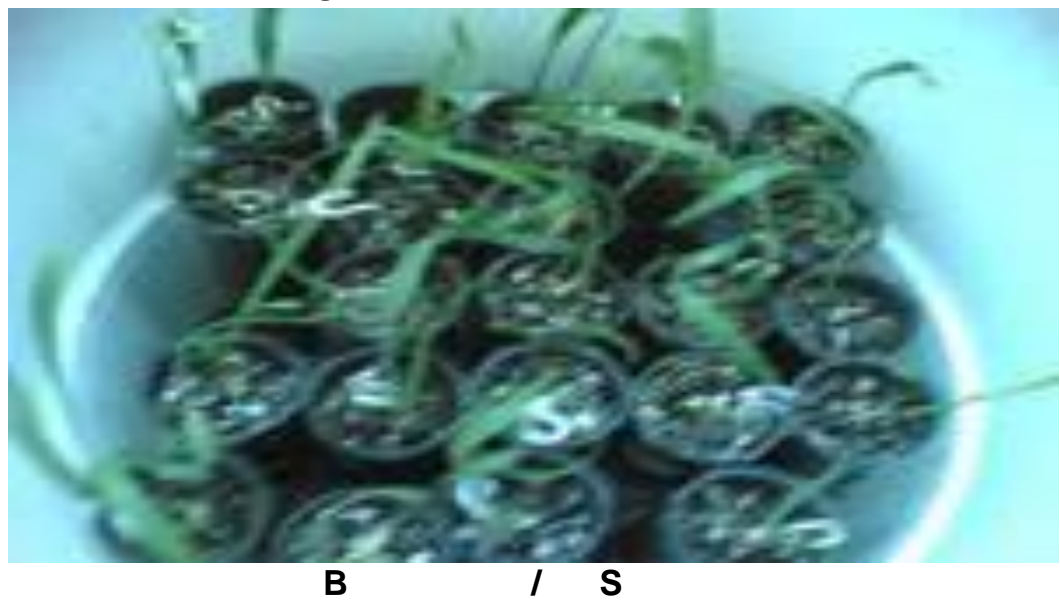

Fig 1: Acclimatization stage of Bartamuda (B) and Sakkoty (S) cv(s) of date palm (Phoenix dactylifera, L.) under the treatment MS+2 IBA (above) and control (below).

\section{REFERENCES}

A, O.A.C, Association of Official Analytical Chemists. (2000). Official Methods of Analysis. Association of Official Agriculture Chemists. $17^{\text {th }}$ Ed. pPub. Washington. DC., USA. 
Al-Jibouri, A. J. M.; Salman, R.M. and Omar, M. S. (1988). Transfer of in vitro regenerated date palms to the soil. Date palm J., 6(2): 390-400.

Al-Khayri , J. M. (2001).Optimization of biotin and thiamine requirements somatic embryogenesis of date palm (phoenix dactylifera $\mathrm{L}$ ). In vitro Cell. Develop. Biol. Plant., 37:4, 453-456.

Al-Salih, A.A.; Al-Jarrah, A.Z.; Badr, S.M. and Craradi, M.T. (1985). A study on the functional anatomy of the first seedling root of date palm. (Biblographic Citation). Date Palm J., 4: 11-14.

Amberger, A. (1954). Einfluß von Kalium und stickstoff auf Ferment and Kolenhydrathaus half von Grunland pflanzen. Z. pflanzenernahr. Dung bodenkunde, 66(11), 3: 211-222.

Bates, L. S.; Waldren R. P. and Teare I. D. (1973). Rapid determination of free proline for water-stress studied. Plant and Soil, 39: 205-207.

Bhansalia, R.R. and Kaul, R.K. (1991). In to future: Date through tissue culture. Indian Hort., 36(3): 6-10.

Bhargava S.C; Saxena S.N and Sharma (2003). In Vitro multiplication of Phoenix dactylifera, (L). J.Plant Biochemistry and Biotechnology12: 4347 ,

Binzell, M. I. and M. Reuveni (1994). Cellular mechanismis of salt tolerance in plant cells. Horticultural-Reviews, (16): 33-69. Binzell, M. I. and M. Reuveni (1994). Cellular mechanismis of salt tolerance in plant cells. Horticultural-Reviews, (16): 33-69.

Booij, I.; Piombo G.; Risterucci J. M.; Thomas D.and Ferry M. (1993a). Sugar and free amino acid composition of five cultivars of dates palm from offshoots or vitro plants in open field.J Agric.Food chem.41: 1553-1557.

Cheng, S. (2003). Effects of heavy metals on plants and resistance mechanisms. Environ. Sci. Pollut. Res., 10: 256-264.

Dubois, M.; Smith F.; Gilles K.A.; Hamilton J.K. and Rebers P.A.(1966). Calorimetric method for determination of sugars and related substances. Anal. Chem., 28 (3): 350-356.

El-Hosiny, Hanan (2002). Effects of some growth factors on structure and growth behaviour of stem shoot tip cultures of date palm (Phoenix dactylifera, L.). M.Sc. Thesis Faculty of Agric Mansoura Univ. Egypt.

El-Hosiny, Hanan (2008). Comparative Physiological and Anatomical Studies on Somaclonal Variations of Date Plam ( Phoenix dactylifera, L ) Tissue Cultures. Ph.D. Thesis Faculty of Agric mansoura Univ. Egypt.

Ghallab A.M.; Naie A.E. and Abdel-Aziz Rania M. (2004). Some physiological studies on increasing water stress tolerate of micropropagated sugar cane plants by using laser irradiation. J. Agric. Sci., 29(5): 2431-2458, Mansoura Univ., Egypt.

Gomez, K.A. and Gomez, A.A. (1984). Statistical Procedures for Agric. Research. $2^{\text {nd }}$ ed. International Rice Res. Inst. John Wiley and Sons, New York, USA.

Hatung, W. (2004). Plant response to stress: Abscisic acid fluxes. Marcel Dekker Inc., New York. Pp. 540-680. 
Helaly, M.N. (1977). Some physiological studies in relation to salt tolerance of Egyptian henbane; Hyoscyamus muticus, L. Ph.D. Thesis, Faculty of Agric.Cairo University.

Helaly, M.N.M.; El-Basyouni S.Z.M. and Salama A.M.. (1985b). Morphological and physiological studies on petunia plants. . $2^{\text {nd }}$ Coft. Agric. Botany Sci., 21-24 Sept., Fac. Of Agric. Mansoura Univ., Egypt.

Helaly, M.N.M.; El-Basyouni S.Z.M.and Arafa A.A. (1985a). Physiological studies on salt tolerance in chamomile plant. $2^{\text {nd }}$ Coft. Agric. Botany Sci., 21-24 Sept., 1: 125-148, Mansoura Univ., Egypt.

Ismail, H.F(2005). Effect of some trace-elements on Zea mays, L plants under saline condition. Ph.D. Thesis Faculty of Agric. Mansoura Univ. Egypt.

Jeffrey, W.D. (1987). Soil Plant Relationships, An Ecological Approch. Groom Helm Ltd., Provident Hous, Bundel Row Backenham, Kenl BR3 IAT.

Kayani, S. A.; Naqvi H. H. and Ting I. p. (1990). Salinity effects on germination and mopbilization of reserves on Jojoba seed. Crop Sci., 30, (3): 704-708.

Mater, A.A. (1986a). In vitro propagation of (Phoenix dactylifera, L). Date Palm J., 4(2): 137-152.

Meinzer, F. C.; Grantz D. A.; Goldstein G. and Saliendra N. Z. (1990). Leaf water relations and maintenance of gas exchange in coffee cultivars grown in drying soil. Plant Physiol., 94:1781-1787.

Naguib, M.I. (1964). Modified Nelson Solution. Effect of serrin on the carbohydrate and nitrogen metabolism during germination cotton seeds. Indian J. Exptl. Biol., 2: 149.

Nasir M. N.; Qureshi R. H; Muhammed A. and Akhtar J. (2000). Comparative studies on two selected sugarcane Lines for differences in physiological traits. Pakistan-Sugar Journal, 15 (1): 52-61.

Passaraki, M. (2002). Handbook of plant and crop physiology. New York. Marcel Dekker Inc. pp. 563-581.

Pierik, R.L.M. (1989). In vitro Culture of Higher Plants. Martinus Nijhoff Publishers, Netherlands.

Plant Physiol. 25: 135-166.

Plummer, D. T. (1978). An Introduction to practical Biochemistry. McGraw-Hill Book Company (UK) Limited. London. New York. P. 174-175, Pp.183184.

Quraishi, A.; Hussain, I.; Ahmed, M.; Rashid, H. and M. Latif (1997). Sustained multiplication of long term embryogenic cultures of date palm and their field performance. Pakistan J. of Botany, 29(1): 135-141.

Salem, S.M.; O.M. El-Shihy; A.M. Ghallab and H.M. Yossef-Ibrahim (2002). Studies on the correlation between resistance against Orobanche and tolerance to salinity in some Vicia Faba cultivars. J. Agric. Sci. Mansoura Univ., 27 (7): 4643-4669.

Sallam, H.A. (1999). Effect of some seed-soaking treatments on growth and chemical component on faba bean plants under saline conditions. Annals of Agric. Sci. Cairo, 44(1): 159-171. 
Helaly, M.N. et al.

Sharon, M. and Shankar, P. C. (1998). Somatic embryogenesis and plant regeneration from: primordia of phoenix dactylifera cv. Tokupi. Indian Journal of Experimental Biology, 36 (5):526-529

Swain, T. and Hills, W. E (1959). The quantitative analysis of phenolic constituent. J. Sci. Food Agric., 10: 63.

Tisserat, B. (1981a). Date palm tissue culture. USDA/ARS Advances in Agriculture Technology, Western Series, 17. Agric. Res. Ser. Oakland, California.

Tisserat, B. (1981b). Production of free-living palms through tissue culture. Date palm J., 1: 43-54.

Tisserat, B. (1982). Factors involves in the production of plantlets from date callus cultures. Euphytica, 3(1): 201-214

Tisserat, B. (1984a). Propagation of date palms by shoot tip cultures. Hort. Sci., 19(2): 230-231.

Tisserat, B. (1984b). Date Palm in Sharp, W.R.; Evans, D.A.; Ammirato, P.V. and Yamado, Y. (eds). Hand Book of Plant Cell Culture, 2, Mc Millian, New York, p 505-545.

Tomlinson, P.B. (1961): Anatomy of the monocotyledons.- Palmae, Clorendon Press, Oxford.

Zein El Din,Amal, R. (2005). Physiological studies on vegetative propagation of some date palm callus using the tissue culture technique. M.Sc. Thesis Faculty of Agric. Ain Shams Univ. Egypt.

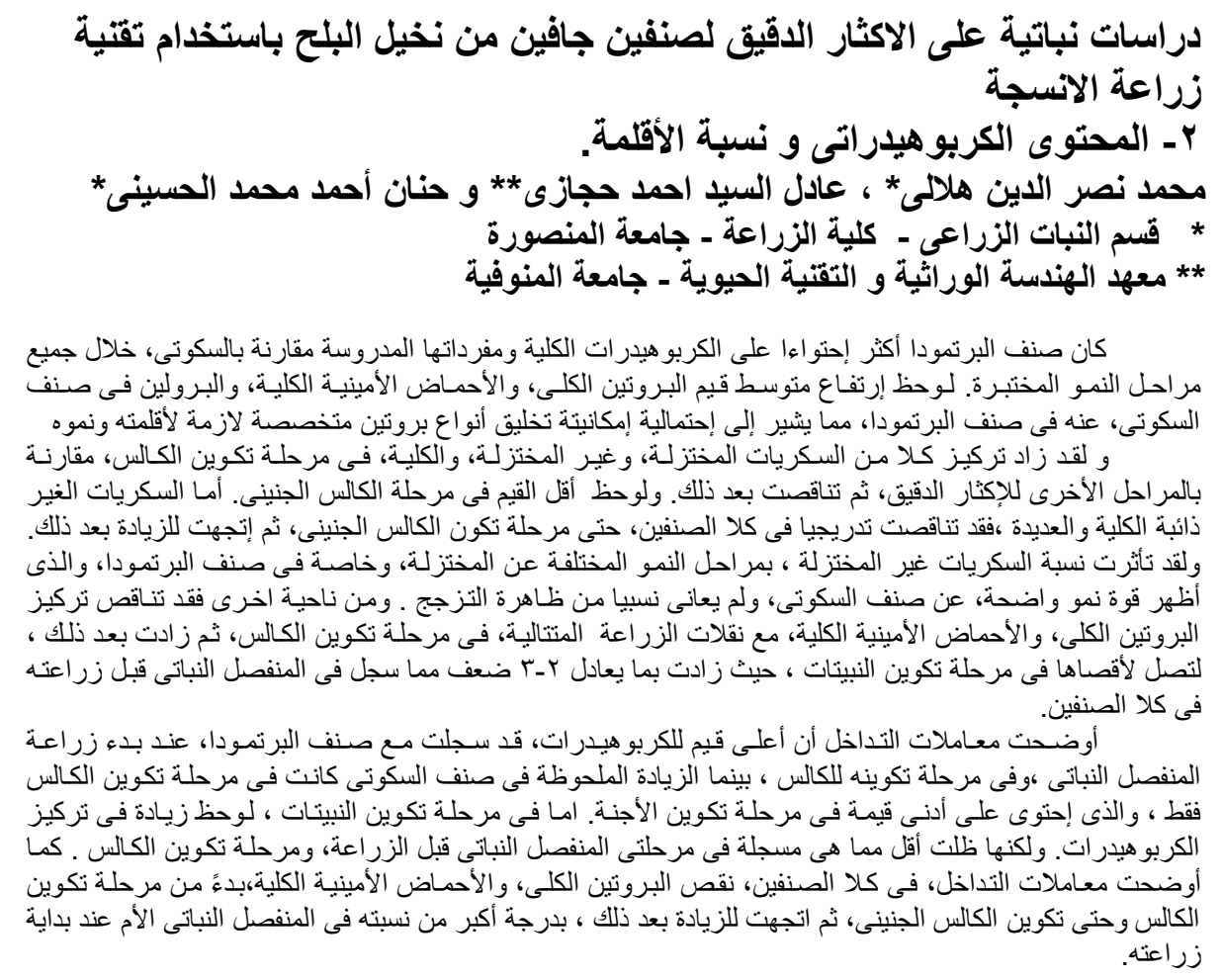



Table 3: Effects of MS basal nutrient media pre-supplemented with or without different types of auxins NAA, IBA and 2.4-D at the level of 1 and $2 \mathrm{mg} / \mathrm{l}$ on the percentage of survivied plantlet, plantlets height $(\mathrm{cm})$ and number of leaves/plantlet throughout the acclimatization (hardening) period (week) of date palm ((phoenix dactylifera, $L$ ) ; Bartamuda and Sakkoty cv(s) micropropagated with indirect embryogenesis.

\begin{tabular}{|c|c|c|c|c|c|c|c|c|c|c|c|c|c|c|c|c|}
\hline \multirow{2}{*}{$\begin{array}{l}\text { Genotype } \\
\text { (cv) }\end{array}$} & \multirow{2}{*}{$\begin{array}{l}\text { Treatments } \\
\mathrm{mg} \mathrm{l}^{-1}\end{array}$} & \multicolumn{4}{|c|}{ \%of Survivied plantlets } & \multirow[t]{2}{*}{ M } & \multicolumn{4}{|c|}{ Plantlets height $(\mathrm{cm})$} & \multirow[t]{2}{*}{ M } & \multicolumn{4}{|c|}{ No of leaves/plantlet } & \multirow[t]{2}{*}{$\mathbf{M}$} \\
\hline & & 12 & 24 & 36 & 48 & & 12 & 24 & 36 & 48 & & 12 & 24 & 36 & 48 & \\
\hline \multirow[t]{8}{*}{ Bartamuda } & MS alone & 25 & 15 & 10 & 5 & 13.75 & 5.7 & 6.2 & 6.9 & 7.3 & 6.53 & 2.00 & 2.00 & 2.25 & 2.38 & 2.16 \\
\hline & MS+1NAA & 80 & 70 & 60 & 55 & 66.25 & 7.8 & 8.5 & 9.00 & 10.6 & 8.3 & 2.13 & 2.25 & 2.38 & 2.50 & 2.32 \\
\hline & MS+2NAA & 85 & 75 & 70 & 65 & 73.75 & 8.2 & 8.6 & 10.2 & 11.1 & 9.53 & 2.25 & 2.25 & 2.50 & 2.63 & 2.41 \\
\hline & $\mathrm{MS}+1 \mathrm{IBA}$ & 85 & 75 & 70 & 65 & 73.75 & 8.8 & 9.2 & 9.8 & 10.9 & 9.68 & 2.13 & 2.25 & 2.50 & 2.75 & 2.41 \\
\hline & $\mathrm{MS}+2 \mathrm{IBA}$ & 90 & 80 & 75 & 70 & 78.75 & 9.2 & 9.8 & 10.4 & 11.6 & 10.25 & 2.25 & 2.38 & 2.50 & 3.00 & 2.53 \\
\hline & $M S+12,4-D$ & 80 & 65 & 55 & 55 & 63.75 & 7.8 & 8.5 & 8.9 & 9.7 & 8.48 & 2.00 & 2.13 & 2.25 & 2.25 & 2.16 \\
\hline & $M S+2$ 2,4-D & 75 & 60 & 50 & 45 & 57.5 & 7.7 & 8.2 & 8.8 & 9.5 & 8.55 & 2.00 & 2.00 & 2.13 & 2.25 & 2.10 \\
\hline & Mean & 75.71 & 62.14 & 57.14 & 50.71 & 61.07 & 7.49 & 8.0 & 7.18 & 9.14 & 8.76 & 2.13 & 2.14 & 2.36 & 2.34 & 2.30 \\
\hline \multirow{8}{*}{ Sakkoty } & MS alone & 30 & 20 & 15 & 10 & 18.75 & 5.5 & 6.1 & 6.8 & 7.1 & 6.38 & 2.00 & 2.00 & 2.25 & 2.25 & 2.13 \\
\hline & MS+1NAA & 80 & 70 & 60 & 55 & 66.25 & 7.6 & 8.9 & 9.2 & 9.9 & 8.9 & 2.13 & 2.25 & 2.38 & 2.50 & 2.31 \\
\hline & MS+2NAA & 85 & 70 & 65 & 60 & 70 & 8.0 & 8.8 & 9.5 & 10.6 & 9.23 & 2.25 & 2.25 & 2.50 & 2.63 & 2.41 \\
\hline & $\mathrm{MS}+1 \mathrm{IBA}$ & 85 & 70 & 60 & 55 & 67.5 & 8.6 & 9.2 & 9.8 & 10.8 & 9.6 & 2.25 & 2.25 & 2.50 & 2.75 & 2.44 \\
\hline & $\mathrm{MS}+2 \mathrm{IBA}$ & 85 & 75 & 65 & 60 & 71.25 & 8.4 & 9.7 & 10.5 & 11.5 & 10.03 & 2.25 & 2.38 & 2.50 & 3.00 & 2.53 \\
\hline & $\mathrm{MS}+12,4-\mathrm{D}$ & 75 & 65 & 55 & 50 & 61.25 & 7.7 & 8.2 & 8.6 & 8.9 & 8.35 & 2.00 & 2.13 & 2.25 & 2.25 & 2.16 \\
\hline & $M S+2$ 2,4-D & 70 & 60 & 50 & 40 & 55 & 7.8 & 8.4 & 8.8 & 9.3 & 8.33 & 2.00 & 2.13 & 2.13 & 2.25 & 2.13 \\
\hline & Mean & 73.57 & 61.43 & 52.86 & 47.14 & 58.57 & 7.41 & 7.96 & 8.49 & 8.91 & 8.64 & 2.13 & 2.18 & 2.36 & 2.52 & 2.31 \\
\hline \multirow{7}{*}{ Mean } & MS alone & 32.5 & 20 & 12.5 & 7.5 & 16.25 & 4.6 & 5.15 & 5.85 & 6.2 & 6.46 & 2.00 & 2.00 & 2.25 & 2.25 & 2.14 \\
\hline & $\mathrm{MS}+1 \mathrm{NAA}$ & 82.5 & 70 & 62.5 & 55 & 66.25 & 7.7 & 8.4 & 8.95 & 9.5 & 8.6 & 2.13 & 2.25 & 2.38 & 2.50 & 2.31 \\
\hline & MS+2NAA & 85 & 72.5 & 67.5 & 60 & 71.18 & 8.1 & 8.5 & 9.05 & 9.95 & 9.38 & 2.25 & 2.25 & 2.50 & 2.63 & 2.41 \\
\hline & $\mathrm{MS}+1 \mathrm{IBA}$ & 85 & 72.5 & 65 & 60 & 70.63 & 8.15 & 8.6 & 9.1 & 9.85 & 9.64 & 2.25 & 2.25 & 2.38 & 2.75 & 2.42 \\
\hline & $\mathrm{MS}+2 \mathrm{IBA}$ & 87.5 & 77.5 & 70 & 65 & 75 & 8.25 & 8.75 & 9.35 & 10.2 & 10.14 & 2.25 & 2.25 & 2.50 & 3.00 & 2.53 \\
\hline & $M S+12,4-D$ & 77.5 & 65 & 57.5 & 52.5 & 62.5 & 7.6 & 8.15 & 8.5 & 8.85 & 8.42 & 2.00 & 2.13 & 2.25 & 2.25 & 2.16 \\
\hline & $M S+2$ 2,4-D & 72.2 & 60 & 50 & 42.5 & 56.25 & 7.75 & 8.3 & 8.7 & 9.10 & 8.44 & 2.00 & 2.00 & 2.13 & 2.32 & 2.13 \\
\hline \multicolumn{2}{|c|}{$\mathrm{N}-\mathrm{LSD}$ at $5 \%$ for } & & & & & & & & & & & & & & & \\
\hline \multicolumn{2}{|l|}{ Genotype; A } & 1.1 & 0.9 & 2.0 & 0.7 & & 0.3 & 0.2 & 0.7 & 0.03 & & 0.03 & 0.05 & 0.03 & 0.02 & \\
\hline \multicolumn{2}{|c|}{ Developmental stage; B } & 1.6 & 1.0 & 2.3 & 0.9 & & 0.4 & 0.2 & 0.9 & 0.05 & & NS & $\mathrm{NS}$ & NS & NS & \\
\hline \multicolumn{3}{|c|}{ GenotypeXDevelopmental AxB) 2.3} & 1.7 & 3.4 & 1.0 & & 0.6 & 0.3 & 1.1 & 0.17 & & 0.05 & 0.09 & 0.07 & 0.06 & \\
\hline
\end{tabular}


J. Agric. Sci. Mansoura Univ., 34 (3): 2041 - 2056, 2009 